\title{
ARTHROPOD ALLERGY AND PUBLIC HEALTH
}

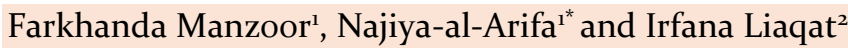

'Department of Zoology, Lahore College for Women University, Lahore

${ }^{2}$ Department of Zoology, Government College University, Lahore

*Corresponding author: najiya.alarifa@lcwu.edu.pk

\section{INTRODUCTION}

Allergic disease, or simply allergy, is a common disorder which affects approximately $40 \%$ of global population (Johansson et al. 200o). It is an allergen-mediated hypersensitivity response, involving diverse immunological mechanisms initiated by specific antibodies or cells (Halliwell et al. 2006). Austrian physician Clemens von Pirquet introduced the term "allergy" almost a century ago in a German medical journal to describe the "altered biological reactivity" of the immune response against allergens in the host (Von Pirquet 1906). With the advent of, and advances in molecular biology, the science of allergy has transformed into a major branch of highly sophisticated human and veterinary medicine (Noli et al. 2013).

In immunological terms, an allergen is an antigen. The allergen itself is a non-toxic, non-invasive protein with the potential to initiate immunogenic type-I hypersensitivity reaction by specific immunoglobulin $\mathrm{E}$ responses when inhaled, ingested or injected (Goldsby et al. 2003). Most allergens in their natural state are soluble proteins, which chiefly exhibit proteolysis amongst other types of enzymatic activities (Morgan and Arlian 2006; Jeong et al. 2010). The allergic reaction is induced by production of IgE and cross linking of the high-affinity IgE receptor (FceRI) on basophil and mast cell surfaces (Kinet 1990; Aalberse 2000). The allergic potential of an allergen is determined by its critical physiochemical properties, such as membranous, mucosal and epithelial permeability, solubility and stability under varying $\mathrm{pH}$ and temperature conditions (Christensen et al. 2008). An allergic reaction is dependent upon the amount of allergen exposure and the consequent aggregation of the receptors (Marshall et al. 1986). Allergy, being an immune-mediated disease, is complex and multifactorial in nature. Evidence suggests that allergic individuals have genetic predisposition (Vercelli 2008; Tan et al. 2012; Kanchan et al. 2021). Key factors affecting the outcome of allergy are a combination of underlying genetic vulnerability and triggering factors, such as immunological dysregulation and environmental influences (Jabbar-Lopez et al. 2020; Kanchan et al. 2021). The term atopy is derived from the Greek word "atopos", meaning out of place, and is typically associated with IgEmediated diseases (Kay 2001). Asthma, atopic eczema, dermatitis and allergic rhinitis are the most frequent manifestations of atopy and are amongst the most common global causes of chronic public health problems. Combination of these diseases is called the atopic triad, as shown in Figure 1 (Devereux and Seaton 2005; Vaillant et al. 2020). The immunopathological hallmark of atopy is type 2 helper cell (Th2) infiltration. An exaggerated immunological response elevates serum IgE levels and induces cytokine production by Th2 cells (Lauzon-Joset et al. 2020; Lee et al. 2021). The concentration and duration of allergen exposure, along with the avidity of allergenspecific interactions, determine the influence of Th1 and Th2 cells in the affected tissues (Constant and Bottomly 1997; Rogers and Croft 1999). Atopic allergic diseases are hereditary and often have a family history (Kay 2001). Several loci have been linked to atopy through candidate gene approach. Polymorphisms in the IgE receptor gene $\left(F_{c} e R I-\beta\right)$ are reportedly associated with severe atopy (Cookson 1999). However, the clinical significance of genetic investigation is unclear, because inheritance of susceptibility genotype does not guarantee allergic phenotype, the environment and lifestyle choices strongly influence disease onset and severity (Noli et al. 2013).

Pakistan is a developing country with a very high burden of both communicable and non-communicable diseases (Sultan and Khan 2013). Although researchers, physicians and healthcare professionals in Pakistan are primarily focusing on infectious diseases, allergenic diseases are mostly ignored. Allergy is a neglected disease in Pakistan and little or incomplete data exists on its prevalence. Patients with allergy symptoms ignore them and neither report nor seek effective treatment (Greiner et al. 2011).

\section{Molecular Mechanisms and Pathophysiology}

Allergen molecules have specific epitopes which upon exposure in a susceptible individual are recognized as antigens by the immune system. B-cell surface receptors bind to these antigens, signaling endosomes for endocytosis and subsequent degradation by proteases enzymes into immunogenic peptides (Janeway et al. 2001). MHC bearing Golgi bodies fuses with proteolytic enzymes to form peptide-loading vesicles, which bind with the immunodominant peptide. The endosome moves to the cell surface, transforming the $\mathrm{B}$ cell into an antigen presenting cell (APC). Helper T-cells (Th1 and Th2) recognize and bind to these B-cell APCs, activating both the T and B-cells (Kinet 1990; Aalberse 2000). A cytokine cascade of interleukin (IL-3, IL-4, IL-5, IL-9, IL-10 and IL13) is initiated by the activated Th2, enhancing B-cell growth, proliferation and differentiation into $\operatorname{IgE}$ producing plasma cells and memory B-cells. Immune cells such as leukocytes (eosinophils, basophils and neutrophils), mast cells and lymphocytes ( $\mathrm{T}$ and B-cells) are also attracted to the site of allergic reaction (Romagnani 2000). 
The B-cell secreted IgE antibodies circulate in the blood and bind to the surface of acute inflammatory immune cells through high-affinity IgE-specific receptors (fc receptors FceRI). These IgE antibody-coated cells become sensitized to this specific allergen. The main effector cells involved in acute allergic reactions are basophils and mast cells, chiefly located in the eyes, nose and gut mucosa. Figure 2 illustrates the sequence of type-I hypersensitivity reaction upon further allergen exposure. Sensitized cells are activated by forming a cross-linked complex between the IgE antibodies and fc receptors on their surface. Activated cells release powerful soluble inflammatory chemical mediators (histamine, prostaglandins, chondroitin sulfate, heparin, leukotrienes, interleukins, and cytokines), protease enzymes (cathepsins, chymase, tryptase and carboxypeptidase), lipid mediators (thromboxanes, prostaglandins and leukotrienes) and cytokines (IL-3, IL-4, IL-5, IL-9, IL-10, IL-13 and TNF-fi) through a process called degranulation (Kinet 1990). As a result surrounding tissue undergoes physiological effects, such as nerve stimulation (itchiness and sneezing), mucosal secretion (rhinorrhea and epiphora), smooth muscle contraction (wheeze and dyspnea) and vasodilation (edema and erythema). Allergen concentration and host susceptibility can lead to classical anaphylaxis (Janeway et al. 2001; Arlian 2002).

\section{Arthropod Allergy}

Over a million species of arthropods have been described, all of which are important to humans due to their economic, ecological or pathological significance. Arthropods of clinical relevance include vectors, parasites and allergen producers (Yong and Jeong 2009). Arthropod proteins of virtually all species may be potent sources of IgE-mediated allergy in susceptible human populations (Kagen 1990; Kim and Hong 2007). Arthropod allergy and characteristics of their allergens have been extensively studied as a major research discipline in parasitology and medical arthropodology.

In recent decades, a rise in arthropod allergy has been reported which is mostly attributed to household arthropods. This trend may be a consequence of modern human lifestyle and extended periods of indoor activities. Economics, lifestyle choices and environment encourage the growth and multiplication of certain arthropods, such as cockroaches and mites, which results in increased human exposure, leading to sensitization or clinical manifestations (Kim and Hong 2007). Arthropod allergies are reported due to ingestion (shellfish allergy caused by crustaceans), inhalation (aeroallergens of mites, roaches and insects), contact (silk proteins) or injection (hymenopteran and formicidae stings) (Arlian 2002). Types of arthropod allergens are illustrated in Figure 3.

Several allergens identified from arthropods are classified, based on their biological functions and molecular structures (Gaffin and Phipatanakul 2009). More than half of major allergens are lipid and fatty acid binding proteins, calycins and lipocalins found in arthropod fluids and secretions (Mantyjarvi et al. 2000; Trompette et al. 2009).

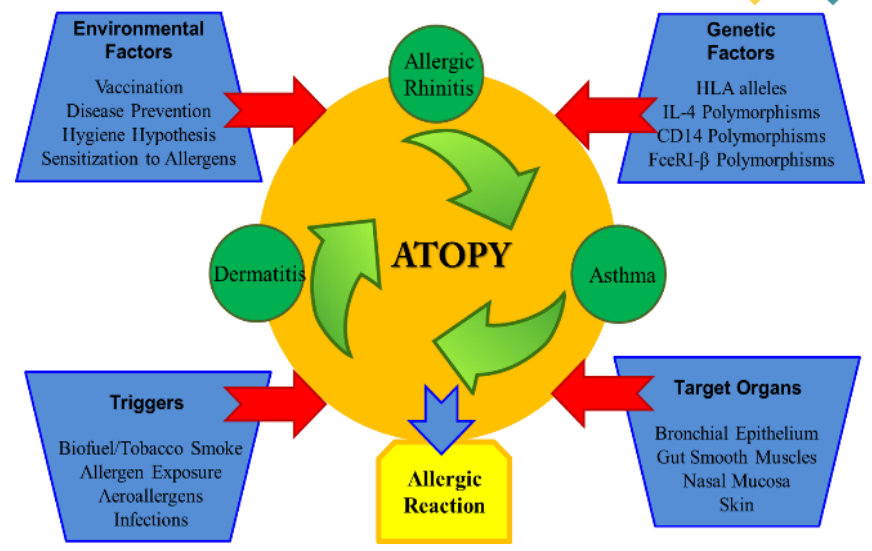

Fig. 1: The atopic triad: Asthma, atopic eczema/dermatitis and allergic rhinitis.

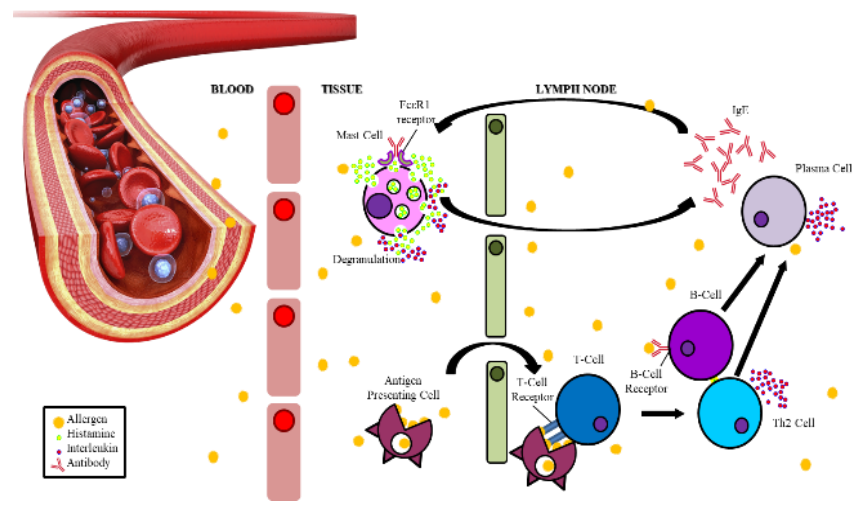

Fig. 2: Acute phase hypersensitivity type-I reaction against an allergen.

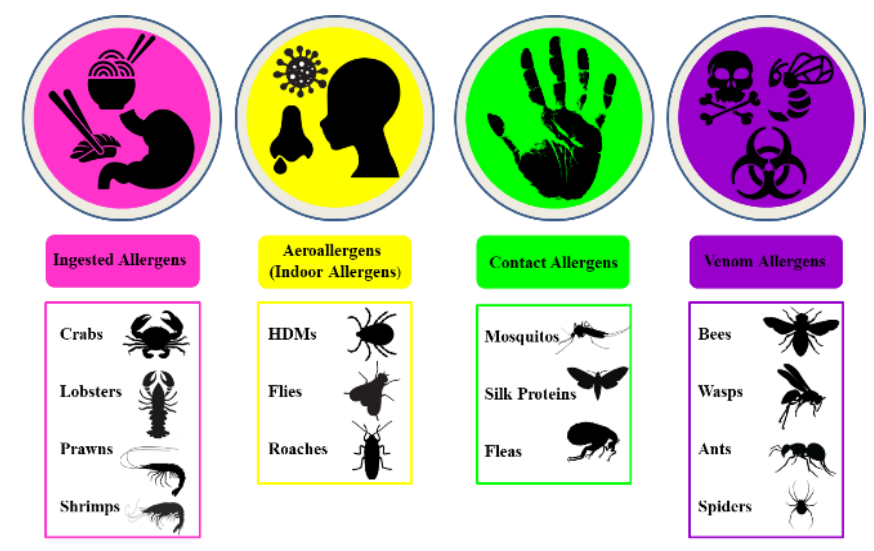

Fig. 3: Types of arthropod allergens.

Evidence suggests that protease activity is also an important allergenic property and is implicated in increased IgE production by direct epithelium damage (Jeong et al. 2006; Chapman et al. 2007). None of the known cockroach allergens exhibit active proteolytic activity, however allergic inflammation is associated with serine proteases found in cockroach extracts (Pomes et al. 2007; Jeong et al. 2008). House dust mite (HDM) allergens are identified as chitinases and have demonstrated an important role in development and mediation of Th2 celldriven inflammation in asthma (O'Neil et al. 2006). Tropomyosin is a heat stable allergen found in edible arthropods, such as crustaceans (Taylor and Lehrer 1996). 
Table 1: Classification of shellfish arthropod species

\begin{tabular}{|c|c|c|c|c|}
\hline Phyla & Sub-Phyla & Class & Order & Common name \\
\hline \multirow{7}{*}{ Arthropoda } & \multirow{7}{*}{ Crustacea } & \multirow{7}{*}{ Malacostraca } & \multirow{7}{*}{ Decapoda } & Shrimps (Caridea) \\
\hline & & & & Prawns (Penaeidae) \\
\hline & & & & Crabs (Brachyura) \\
\hline & & & & Lobsters (Nephropidae) \\
\hline & & & & Crayfish (Cambarus) \\
\hline & & & & Spiders \\
\hline & & & & Mites \\
\hline \multirow{4}{*}{$\begin{array}{l}\text { Arthropoda } \\
\text { Arthropoda }\end{array}$} & \multirow{4}{*}{$\begin{array}{l}\text { Chelicerates } \\
\text { Myriapoda }\end{array}$} & Arachnida & \multirow[t]{4}{*}{ Araneae } & Dust Mites \\
\hline & & Xiphosura & & Horseshoe Crab \\
\hline & & Chilopoda & & Centipedes \\
\hline & & & & Millipedes \\
\hline
\end{tabular}

Table 2: List of identified and characterized shellfish allergens (Radauer et al. 2008)

\begin{tabular}{|c|c|c|c|c|}
\hline Allergen & $\begin{array}{l}\text { Molecular } \\
\text { Weight }\end{array}$ & $\begin{array}{l}\text { Heat } \\
\text { Stability }\end{array}$ & $\begin{array}{ll}\text { IgE } & \text { Route of } \\
\text { Binding } & \text { Exposure }\end{array}$ & f Physiological Function \\
\hline Tropomyosin & $34-38 \mathrm{kDa}$ & $\begin{array}{l}\text { Highly } \\
\text { heat stable }\end{array}$ & $\begin{array}{l}\text { Reactive Ingestion } \\
\text { Inhalation }\end{array}$ & $\begin{array}{l}\text { Actin binding } \\
\text { Regulation of myosin and troponin }\end{array}$ \\
\hline Arginine Kinase & $40-45 \mathrm{kDa}$ & Labile & $\begin{array}{l}\text { Reactive Ingestion } \\
\text { Inhalation }\end{array}$ & $\begin{array}{l}\text { Catalyst } \\
\text { Reversible transfer ATP phosphoryl group to arginine }\end{array}$ \\
\hline $\begin{array}{l}\text { Myosin Light } \\
\text { Chain }\end{array}$ & $17-20 \mathrm{kDa}$ & Stable & Reactive Ingestion & Regulation of smooth muscle contraction in the presence of MLC kinase \\
\hline $\begin{array}{l}\text { Sarcoplasmic } \\
\text { calcium Binding } \\
\text { Protein }\end{array}$ & $20-25 \mathrm{kDa}$ & Stable & Reactive Ingestion & $\begin{array}{l}\text { Calcium buffer } \\
\text { Cytosolic calcium }\left(\mathrm{Ca}^{2+}\right) \text { binding } \\
\text { Regulation of calcium based signaling }\end{array}$ \\
\hline Troponin C & $20-21 \mathrm{kDa}$ & Unknown & Reactive Ingestion & $\begin{array}{l}\text { Muscle contraction } \\
\text { Calcium binding } \\
\text { Regulation of actin and myosin }\end{array}$ \\
\hline $\begin{array}{l}\text { Triosephosphate } \\
\text { Isomerase }\end{array}$ & $28 \mathrm{kDa}$ & Labile & $\begin{array}{l}\text { Reactive Ingestion } \\
\text { Inhalation }\end{array}$ & $\begin{array}{l}\text { Key glycolysis enzyme } \\
\text { Catalyst } \\
\text { Conversion of dihydroxyacetone phosphate to glyceraldehyde 3-phosphate }\end{array}$ \\
\hline
\end{tabular}

\section{Ingested Arthropod Allergens}

Seafood is an important part of human diet. Its consumption has increased in recent years due to growing international trade and distribution of marine products across many countries. However, seafood allergy is one of the most prevalent causes of food induced anaphylaxis in the world. It is more than twice as prevalent as peanut allergy (Sicherer et al. 2004). Shellfish are a common cause of allergic anaphylaxis, affecting children and adults of all ages however, it is 5 times more prevalent amongst adults than children (Lopata et al. 2016; Sicherer and Sampson 2010). Studies have shown that allergic reaction in sensitized individuals can not only be elicited by shellfish ingestion but through air-borne shellfish allergens as well. This is especially evident from occupational risk studies (Gautrin et al. 2010; Bonlokke et al. 2012; Kamath et al. 2014).

\section{Shellfish and Crustacean Allergens}

Shellfish are classified into one chordate and two invertebrate groups, Mollusca and Arthropoda (crustaceans). Phylogenetically, arthropod shellfish or crustaceans are related to arachnids and insects (Afzaal et al. 2016). Classification of arthropod shellfish species is shown in Table 1. More than 50,000 crustacean species have been described (Chan 1998). Many such varieties are used for human consumption, either cooked or raw.
Shellfish allergy is the most prevalent of the eight common food allergens inculpated in 90\% type-I hypersensitivity reactions to food (Rona et al. 2007). Majority (62\%) of arthropod shellfish allergies are attributed to prawns, followed by crabs and lobsters (Sicherer et al. 2004). Six major shellfish allergens have been identified from crustaceans (Table 2) and are registered in the International Union of Immunological Societies (IUIS) Allergen Database (www.allergen.org) (Radauer et al. 2008). These allergenic proteins are highly water soluble light molecules with the ability to maintain stability at high heat and have an acidic isoelectric point (Sun and Lopata 2010). The list of characterized crustacean allergens is shown in Table 3.

\section{Prevalence and Epidemiology}

Approximately $2 \%$ of global population is affected by shellfish allergy. It has a particular impact in the AsiaPacific region, where seafood consumption is the highest in the world (Lee et al. 2012). After Japan and China, America is the third largest seafood consumer in the world (Sicherer et al. 2004). Overall prevalence of shellfish allergy in the western world (Canada, USA and Europe) is estimated to be $0.6 \%$ (Rona et al. 2007). Iceland has the highest seafood consumption rates in Europe, followed by Portugal, Norway, Spain, France, United Kingdom and Germany (Lopata et al. 2010). 
While majority of allergen studies in Pakistan are focused on aeroallergens such as pollen and HDMs, shellfish allergies are mostly ignored. A recent local study involving a small sample $(n=149)$ has reported shellfish allergy as the most prevalent of the tested food allergens, implicating crabs $(70 \% ; n=39)$ and prawns $(46 \% ; n=26)$ (Hussain et al. 2020). However, clinical record has revealed that approximately $90 \%$ allergic patients suffered from aeroallergen sensitization, whereas only $10 \%$ had food allergies (Hussain et al. 2019). This may be due to lower seafood consumption rates in Pakistan. According to the Food and Agriculture Organization (FAO) food balance sheet (FBS) for South East Asia, Pakistan ranked the lowest in seafood consumption rates ( $0.9 \mathrm{~kg}$ per capita per year) in 2015. This figure was even less in 2011 ( $0.6 \mathrm{~kg}$ per capita). Even though seafood in Pakistan is consumed in coastal provinces of Sindh $(1.6 \mathrm{~kg})$ and Balochistan (2.4 $\mathrm{kg}$ ), its consumption is recorded to be very less in Punjab $(0.2 \mathrm{~kg})$ and even less in the Northern regions of Khyber
Pakhtunkhwa (0.05 kg) (FAO-FBS 2015 online resource). Some common shellfish species found in Pakistan are shown in Figure 4.

\section{Clinical Manifestations}

Allergic reaction to ingested arthropod allergens is symptomatically similar to any of the eight major allergic reactions. The severity of reaction may vary from tolerable to fatal. Atopic individuals are at a higher risk of developing anaphylactic reaction to food allergens. Itching and angioedema of the lips, mouth and pharynx is usually immediate i.e., within 2 hours of consumption, however late-phase reaction may take up to 8 hours (Villacis et al. 2006). Respiratory distress, particularly oral allergy syndrome, is experienced due to ingested allergens like crustacean (Dohi et al. 1991). Typical type-I hypersensitivity reaction due to ingested allergens are given in Table 4.

Table 3: Characterized crustacean allergens (IUIS Allergen Nomenclature)

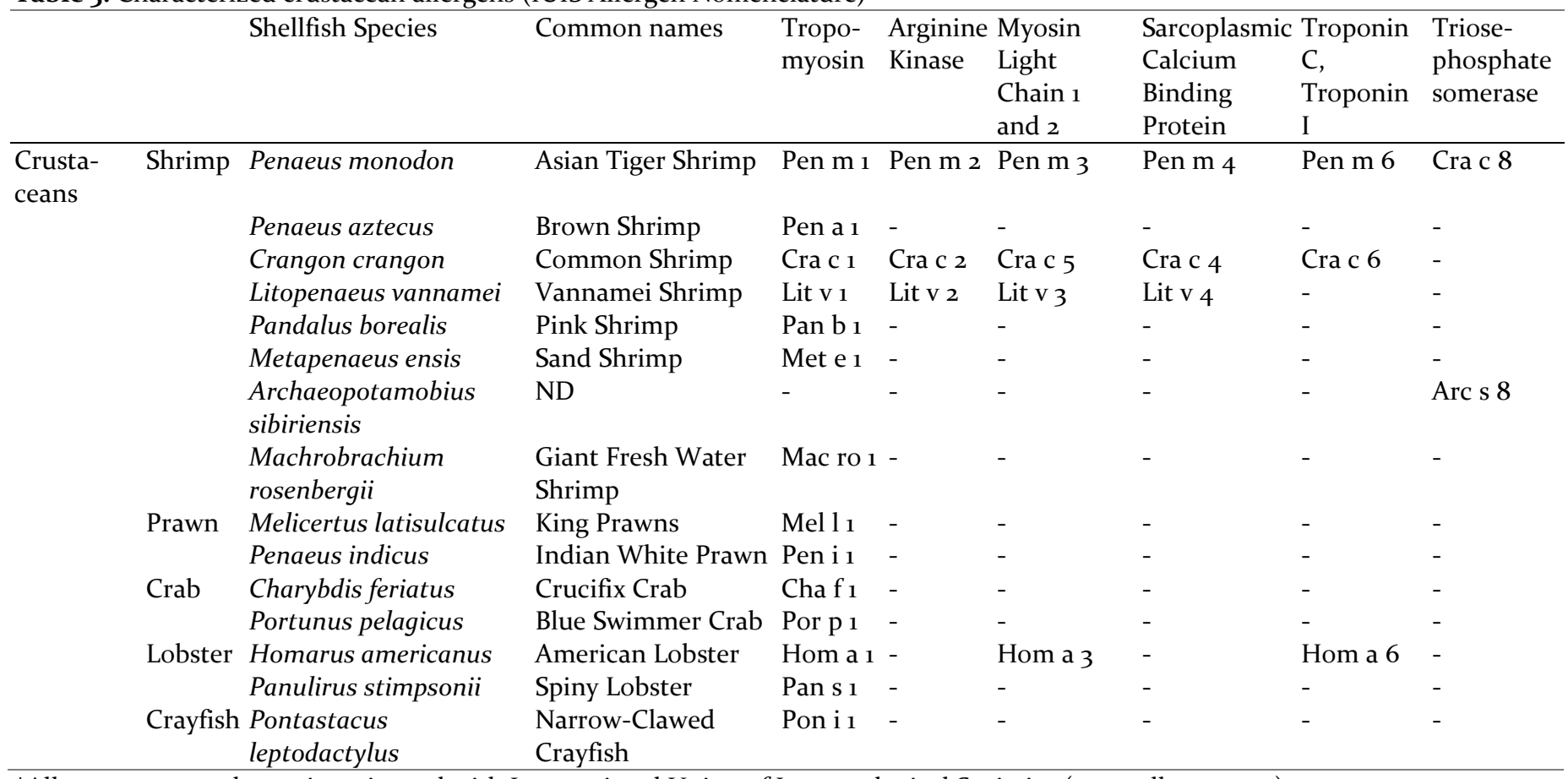

*Allergens nomenclature is registered with International Union of Immunological Societies (www.allergen.org).

Table 4: Type-I hypersensitivity reaction due to ingested allergens

\begin{tabular}{llll}
\hline Time & Severity & \multicolumn{2}{l}{ Symptoms } \\
\hline Immediate & Mild & - & Facial, mouth or tongue tingling \\
& & - & Urticaria, itching or eczema \\
Within 1 to 2 hours & - & Angioedema of the face, lips, tongue or throat \\
& Tolerable & - & Wheeze or nasal congestion \\
& & - & Breathing difficulty \\
Within 8 hours & - & Nausea or vomiting \\
& Anaphylaxis & - & Abdominal pain or diarrhea \\
Chronic sensitization & - & Airway constriction manifesting as a throat lump \\
& & - & Cevere drop in blood pressure and vitals \\
& & - & Aightheadedness, dizziness or loss of consciousness \\
& & - & Extreme sensitivity to trace amounts of allergen
\end{tabular}




\section{Prevention and Management}

As with all types of allergies, prevention of ingested allergens such as shellfish allergy is to avoid seafood and shellfish products. Even trace amounts may result in severe immunological reaction. Shellfish is rarely a hidden food ingredient, which makes it easier to avoid when dinning out. However, seafood flavoring, shellfish stock, oils and cross-contamination through pans and utensils pose a high risk to allergic individuals. Further, crosscontamination may occur in markets, food stores, factory packaged materials where shellfish are prepared, processed or stored. Some individuals may suffer an allergic reaction due to air-borne or even through contact with shellfish allergens. A medical alert bracelet worn at all times, especially when eating out, is also a good management practice.

\section{Arthropod Aeroallergens (Indoor Allergens)}

Arthropod derived aeroallergens are potent inducers of respiratory inflammation. Arthropod secretory or excretory materials induce IgE responses. Inhalation of environmental arthropod allergens (house dust mites, cockroaches, moths and butterflies) may induce persistent airway diseases such as asthma (Kang and Chang 1985). Population fluctuations in indoor arthropods are usually very slight, which consequently results in perennial allergy instead of seasonal allergy unlike pollen and other aeroallergens (Yong and Jeong 2009; Calderón et al. 2015). Although true allergens such as Anisakis simplex antigen (Ani s 1) have been identified (Anisakis spp. larvae), most arthropod-derived materials implicated in increased IgE levels are considered allergens (Ibarrola et al. 2008).

\section{House Dust Mites (HDMs) Allergens}

Dust mites are taxonomically classified in the class Arachnida, which makes them phylogenetic relatives of scorpions, spiders and centipedes (Colloff 1998; Esch et al. 2001). More than 40 HDM species have been described. The most common of these are shown in Figure 5. HDMs are medically important due to their role in allergy and atopy (Dhaliwal et al. 2021). Allergic asthma and rhinitis are associated with HDMs prevalence (Terreehorst et al. 2002; Li et al. 2013). HDM larvae have 3 pairs of legs, whereas adults have an additional pair of legs, totaling in 4 pairs. They are mostly found in human dwellings and indoor environments, such as settled dust, pillows, blankets, mattresses and bedding. Food sources include human skin scales, cotton fibers, wood, paper and synthetic materials. Water is absorbed from air. Most favorable growth and sustainability conditions include 23$30 \circ \mathrm{C}$ temperature and $80-90 \%$ relative humidity, which makes HDM infestations, particularly destructive in tropical and sub-tropical coastal cities (Guerrant et al. 2006).

Mite-derived allergens enter the respiratory track through inhalation. They vary in size, ranging from very small (1.1$4.7 \mu \mathrm{m})$ to larger $(>4.7 \mu \mathrm{m})$ particles. Large particles, even in smaller quantities, can elicit more substantial earlyphase immune response (Casset et al. 2006), however smaller particles can penetrate far deeper into the lungs (Custovic et al. 1999). HDM allergens manifest as rhinitis, bronchial asthma, and rarely-conjunctivitis. To date more than 24 groups of HDM allergenic proteins have been identified and characterized (Table 5). HDM allergens are potent antigens, which orchestrate combined effects of both the innate and the adaptive immune responses. They distort the immune response by mimicking virulent pathogen-associated molecular patterns and activating multiple routes (Wang 2013). They may initiate IgE independent activation of mast cells, causing direct damage to the epithelial cells of the respiratory tract (Takai and Ikeda 2011). Whereas, HDM immunogenic components such as epitopes and proteases along with structural polysaccharides derived from HDM ligands and exoskeleton cause IgE-dependent allergic responses through $\mathrm{CD}_{4}{ }^{+}$and $\mathrm{T}_{\mathrm{H}^{2}}$ cell activation (Jacquet 2013; Wang 2013). This combined effect of the immune responses is the therapeutic barrier marring clinical efficacy.

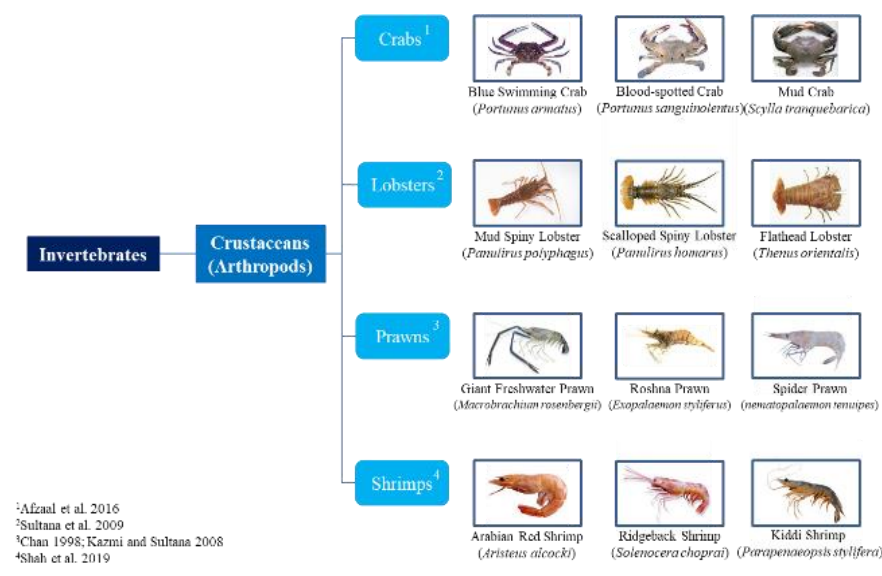

Fig. 4: Common commercial shellfish species from Pakistan.

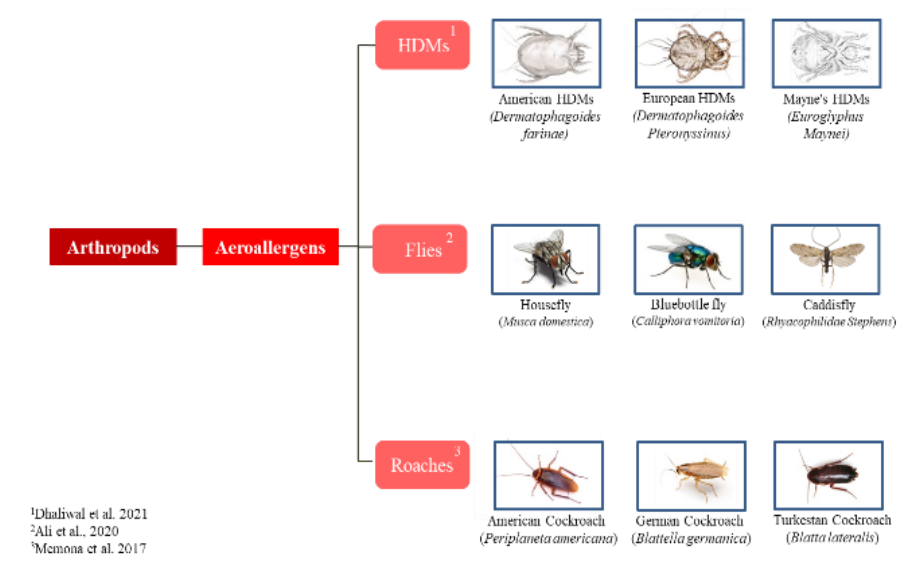

Fig. 5: Common aeroallergen producing arthropod species in Pakistan.

\section{Prevalence and Epidemiology}

It is estimated that $65-130$ million persons or $1-2 \%$ of the global population is affected by HDMs (Colloff 1998). Three HDM species, Dermatophagoides pteronyssinus, 
Dermatophagoides farinae and Euroglyphus maynei, are the most common dust mites by density and species prevalence (Arlian et al. 1992). Regional climate influences HDMs population density, HDM allergen being highest in summer and lower during winter. Indoor microclimate plays a dramatically crucial role. Air-conditioning has been reported to significantly reduce HDM allergens (Lintner and Brame 1993). However, geographical variations in HDM species dominance are strong indicators of specialist adaptation (Thomas 2010). Prevalence of HDM allergy is dependent on the density of exposure. Settled dust provides a detrital habitat for HDMs and serves as a reservoir of organic macromolecules, such as cellulose (textile fibers), keratin (human skin scales) and chitin (fungal hyphae and mite cuticles), along with other HDM dietary sources pollen, bacteria and microscopic spores (Calderón et al. 2015). It has been noted that HDM densities were decreased in houses furnished with new carpets, curtains and mattresses (Simpson et al. 2002).

\section{Clinical Manifestations}

HDM allergen is perennial, since HDM inhabit mattresses, bedcovers, blankets and pillows (Yong and Jeong 2009; Calderón et al. 2015). This causes year-round allergy symptoms, which mostly occur during late night or early morning. The most common HDM allergens are Der $\mathrm{p} 1$, Der p 2, Der p 23, Der f 1 and Der $f$ 2. These allergens target $\mathrm{CD}_{23}$ and $\mathrm{CD}_{25}$ triggering release of immunoglobulin E (Chapman et al. 2007). Catalytic inactivation of alpha antitrypsin by the most potent HDM allergen Der p 1, makes the lower respiratory tract vulnerable to proteinases mediated damage causing airway inflammation, which is extremely devastating in asthmatics (Wang et al. 2021).

Table 5: HDM allergen groups and their immunological roles (IUIS Allergen Nomenclature)

\begin{tabular}{|c|c|c|c|c|c|}
\hline \multicolumn{3}{|c|}{ Allergen Identified Molecular } & \multicolumn{2}{|c|}{ Molecular Quantitative } & \multirow[t]{2}{*}{ Species } \\
\hline Group & Allergens & Category & Weight & Allergenicity & \\
\hline \multirow[t]{8}{*}{1.} & Blo t 1 & Cysteine & $25 \mathrm{kDa}$ & $80 \%$ IgE binding & Blomia tropicalis \\
\hline & Der $f_{1}$ & Protease & & frequency & Dermatophagoides farina \\
\hline & Der $\mathrm{m} 1$ & & & & Dermatophagoides microceras \\
\hline & Der p 1 & & & & Dermatophagoides pteronyssinus \\
\hline & Der s 1 & & & & Dermatophagoides siboney \\
\hline & Eur m 1 & & & & Euroglyphus maynei \\
\hline & Pso o 1 & & & & Psoroptes ovis \\
\hline & Sar s 1 & & & & Sardinops sagax \\
\hline
\end{tabular}

Role in Immunity

- Production of chemokines, cytokines and growth factors

- Production and promotion of pro- $\mathrm{T}_{\mathrm{H}^{2}}$ polarization

- Inflammatory cell recruitment

- Airway remodeling

- Disruption of epithelial junctions to increase permeability

- Degranulation of mast cells and eosinophils

- Fibroblast maturation

- Proliferation of smooth muscles

2. $\quad$ Aca $\mathrm{s} 2$ MD-2-like lipid- $14 \mathrm{kDa}$

Ale o 2 binding protein

Blot 2

Der f 2 Niemann-Pick

Der p 2 C2 homologue

Der $\mathrm{s} 2$

Eur $\mathrm{m} 2$

Gly d 2

Lep d 2

Pso o 2

Sui $\mathrm{m} 2$

Tyr p 2

3.

Blot $3 \quad$ Trypsin-like $\quad 25 \mathrm{kDa}$

Der $\mathrm{f}_{3}$ serine protease

Der $\mathrm{p} 3$

Der $\mathrm{s}$

Eur $\mathrm{m}_{3}$

Gly d 3

Lep d 3

Sar 83

Tyr p 3
$80 \%$ IgE binding frequency

Acarus siro

Anacardium occidentale Blomia tropicalis

Dermatophagoides farina

Dermatophagoides pteronyssinus - Inflammatory cell

Dermatophagoides siboney

Euroglyphus maynei

Glycyphagus domesticus

Lepidoglyphus destructor

Psoroptes ovis

Suidasia medanensis

Tyrophagus putrescentiae

$16 \%$ to $100 \%$ IgE Blomia tropicalis

binding frequency Dermatophagoides farinae

Dermatophagoides siboney

Euroglyphus maynei

Glycyphagus domesticus

Lepidoglyphus destructor

Sarcoptes scabiei

Tyrophagus putrescentiae
- Production of chemokines and cytokines

- Promotion of $\mathrm{T}_{\mathrm{H}^{2}}$ polarization recruitment

- Molecular mimicry of MD-2 or NPC2-like proteins

- Activation of TLR2 and TLR4 on airway epithelium

- C-Type Lectin Receptor binding on dendritic cells by glycosylation

- Release of TNF- $\alpha$

- Production of chemokines, cytokines and growth factors - Production and promotion

- Inflammatory cell recruitment

- Airway remodeling

- Disruption of epithelial junctions to increase permeability

- Degranulation of mast cells and eosinophils of pro- $\mathrm{T}_{\mathrm{H}^{2}}$ polarization 
- Fibroblast maturation

- Proliferation of smooth muscles

4.

Blo t $4 \quad \alpha$-Amylase

Der $\mathrm{f}_{4}$

Der p 4

Eur $\mathrm{m} 4$

5. Blo t 5

Der $\mathrm{f}_{5}$

Der p 5

Gly d 5

Lep d 5

\section{Lipid-binding $\quad 15 \mathrm{kDa}$} protein
$56 \mathrm{kDa}$

$40 \%$ to $46 \% \operatorname{IgE}$

binding frequency

$50 \%$ to $70 \% \operatorname{IgE}$

binding frequency
Blomia tropicalis
Dermatophagoides farinae

Dermatophagoides pteronyssinus Euroglyphus maynei

\section{Blomia tropicalis}

Dermatophagoides farinae

Glycyphagus domesticus

Lepidoglyphus destructor
Unknown

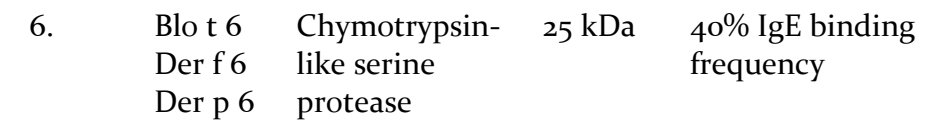

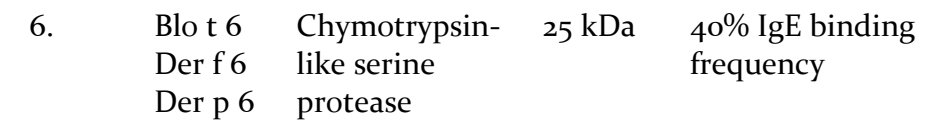

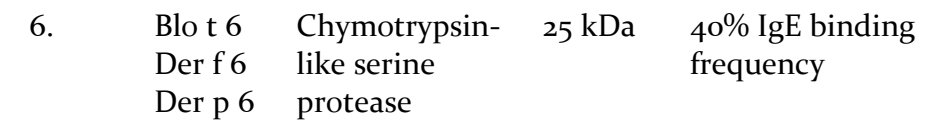

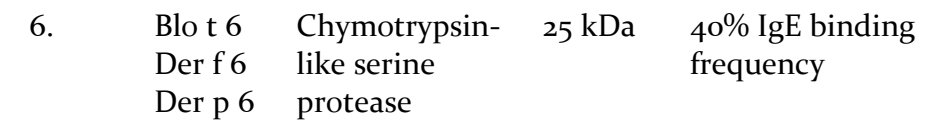

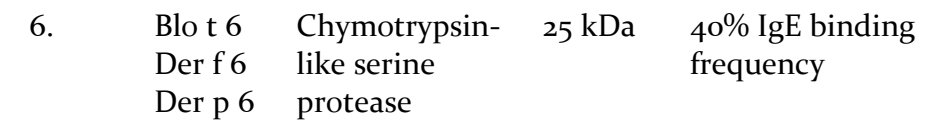

7.

\section{Blo t 7 \\ Der $\mathrm{f}_{7}$}

Der $\mathrm{p} 7$

Gly d 7

Lep d 7

$\begin{aligned} & \text { Lipid-binding } 24 \mathrm{kDa} \\ & \text { protein }\end{aligned}$
$\begin{aligned} & 50 \% \text { IgE binding } \\ & \text { frequency }\end{aligned}$

$\begin{array}{llll}\text { Blo t 8 } & \text { Glutathione-S- } & 26 \mathrm{kDa} & \begin{array}{l}20 \% \text { to } 40 \% \text { IgE } \\ \text { binding frequency }\end{array} \\ \begin{array}{l}\text { Ger p 8 } \\ \text { Lly d } 8\end{array} & \text { transferase } & & \\ \text { Lep d 8 } & & & \\ \text { Pso o 8 } & & & \\ \text { Sar s 8 } & & \\ \text { Blo t 9 } & \text { Collagenolytic- } & 29 \mathrm{kDa} & \begin{array}{l}90 \% \text { IgE binding } \\ \text { frequency }\end{array} \\ \text { Der f 9 } & \text { like serine } & & \\ \text { Der p 9 } & \text { protease } & & \end{array}$

Blomia tropicalis

Dermatophagoides farinae

Dermatophagoides pteronyssinus
Blomia tropicalis

Dermatophagoides farinae Dermatophagoides pteronyssinus - Activation of Toll-Like Glycyphagus domesticus Lepidoglyphus destructor of pro- $\mathrm{T}_{\mathrm{H}^{2}}$ polarization Pathways
- Production of chemokines, cytokines and growth factors

- Production and promotion of pro- $\mathrm{T}_{\mathrm{H}^{2}}$ polarization

- Inflammatory cell recruitment

- Stimulation of innate immunity by hydrophobic ligand binding

- Activation of Toll-Like Receptor (TLR) Signaling Pathways

- Production of chemokines, cytokines and growth factors

- Production and promotion of pro- $\mathrm{T}_{\mathrm{H}^{2}}$ polarization

- Inflammatory cell recruitment

- Airway remodeling

- Disruption of epithelial junctions to increase permeability

- Degranulation of mast cells and eosinophils

- Fibroblast maturation

- Proliferation of smooth muscles

- Production and promotion Receptor (TLR) Signaling

- Stimulation of innate immunity

- Structural similarity to lipopolysaccharides (LPS)binding proteins

- Acts as ligand for other bacterial ligands

Blomia tropicalis

Dermatophagoides pteronyssinus

Glycyphagus domesticus Unknown

Lepidoglyphus destructor

Psoroptes ovis

Sarcoptes scabiei

Blomia tropicalis

Dermatophagoides farinae

- Production of chemokines, cytokines and growth factors Dermatophagoides pteronyssinus - Disruption of epithelial junctions to increase permeability

- Production and promotion of pro- $\mathrm{T}_{\mathrm{H}^{2}}$ polarization

- Inflammatory cell recruitment

- Airway remodeling

- Degranulation of mast cells and eosinophils 
- Production of chemokines, cytokines and growth factors

\begin{tabular}{|c|c|c|c|c|c|c|}
\hline \multirow[t]{8}{*}{10.} & Blo t 10 & \multirow[t]{8}{*}{ Tropomyosin } & \multirow[t]{8}{*}{$35 \mathrm{kDa}$} & \multirow{8}{*}{$\begin{array}{l}50 \% \text { to } 95 \% \text { IgE } \\
\text { binding frequency }\end{array}$} & \multicolumn{2}{|l|}{ Blomia tropicalis } \\
\hline & Der $f_{10}$ & & & & \multicolumn{2}{|l|}{ Dermatophagoides farinae } \\
\hline & Der g 10 & & & & \multicolumn{2}{|l|}{ Dermanyssus gallinae } \\
\hline & Der $\mathrm{p} 10$ & & & & \multicolumn{2}{|c|}{ Dermatophagoides pteronyssinus Unknown } \\
\hline & Gly d 10 & & & & \multicolumn{2}{|c|}{ Glycyphagus domesticus } \\
\hline & Lep d 10 & & & & \multicolumn{2}{|l|}{ Lepidoglyphus destructor } \\
\hline & Pso o 10 & & & & \multicolumn{2}{|l|}{ Psoroptes ovis } \\
\hline & Tyr p 10 & & & & \multicolumn{2}{|l|}{ Tyrophagus putrescentiae } \\
\hline \multirow[t]{5}{*}{11.} & Blo t 11 & \multirow{5}{*}{ Paramyosin } & \multirow{5}{*}{$100 \mathrm{kDa}$} & \multirow{5}{*}{$\begin{array}{l}80 \% \text { IgE binding } \\
\text { frequency }\end{array}$} & \multicolumn{2}{|l|}{ Blomia tropicalis } \\
\hline & Der $f_{11}$ & & & & \multicolumn{2}{|l|}{ Dermatophagoides farinae } \\
\hline & Der p 11 & & & & \multicolumn{2}{|c|}{ Dermatophagoides pteronyssinus Unknown } \\
\hline & Pso o 11 & & & & \multicolumn{2}{|c|}{ Psoroptes ovis } \\
\hline & Sar s 11 & & & & \multicolumn{2}{|l|}{ Sarcoptes scabiei } \\
\hline \multirow[t]{3}{*}{12.} & Blo t 12 & \multirow[t]{3}{*}{ Chitinase } & $14 \mathrm{kDa}$ & $50 \%$ IgE binding & Blomia tropicalis & \\
\hline & Der p 12 & & & frequency & Dermatophagoides pteronyssinus & Unknown \\
\hline & Lep d 12 & & & & Lepidoglyphus destructor & \\
\hline 13. & Aca s 13 & Lipocalin & $15 \mathrm{kDa}$ & $10 \%$ to $20 \% \operatorname{IgE}$ & Acarus siro & - Activation of Toll-Like \\
\hline & Blot 13 & & & binding frequency & Blomia tropicalis & Receptor (TLR) Signaling \\
\hline & Der f 13 & Fatty acid & & & Dermatophagoides farinae & Pathways \\
\hline & Gly d 13 & binding protein & & & Glycyphagus domesticus & - TLR and $\mathrm{T}_{\mathrm{H}^{2}}$ cells \\
\hline & Lep d 13 & & & & Lepidoglyphus destructor & polarization \\
\hline & Try p 13 & & & & Tyrophagus putrescentiae & \\
\hline 14. & Blo t 14 & Vitellogenin/ & $177 \mathrm{kDa}$ & 90\% IgE binding & Blomia tropicalis & - Activation of Toll-Like \\
\hline & Der f 14 & apolipophorin- & & frequency & Dermatophagoides farinae & Receptor (TLR) Signaling \\
\hline & Der p 14 & like & & & Dermatophagoides pteronyssinus & Pathways \\
\hline & Eur $\mathrm{m} 14$ & & & & Euroglyphus maynei & - TLR and $\mathrm{T}_{\mathrm{H}^{2}}$ cells \\
\hline & Pso o 14 & & & & Psoroptes ovis & polarization \\
\hline & Sar s 14 & & & & Sarcoptes scabiei & - IL-4 and IL-13 production \\
\hline 15 . & Der f 15 & Chitinase & $63 \mathrm{kDa}$ & $70 \%$ IgE binding & Dermatophagoides farinae & - Mostly unknown \\
\hline & Der p 15 & & & frequency & Dermatophagoides pteronyssinus & $-\mathrm{T}_{\mathrm{H}^{2}}$ cells polarization \\
\hline 16. & Der f 16 & Gelsolin & $55 \mathrm{kDa}$ & $50 \% \operatorname{IgE}$ binding & Dermatophagoides farinae & \\
\hline & & & & frequency & & Unknown \\
\hline 17. & Der f 17 & $\begin{array}{l}\text { Calcium binding } \\
\text { EF protein }\end{array}$ & $30 \mathrm{kDa}$ & $\begin{array}{l}35 \% \text { IgE binding } \\
\text { frequency }\end{array}$ & Dermatophagoides farinae & Unknown \\
\hline 18. & Blo t 19 & Chitinase-like & $60 \mathrm{kDa}$ & $55 \%$ IgE binding & Blomia tropicalis & - Mostly unknown \\
\hline & Der $\mathrm{f} 18$ & protein & & frequency & Dermatophagoides farinae & $-\mathrm{T}_{\mathrm{H}^{2}}$ cells polarization \\
\hline & Der p 18 & & & & Dermatophagoides pteronyssinus & \\
\hline 19. & Blo t 19 & $\begin{array}{l}\text { Antimicrobial } \\
\text { peptide }\end{array}$ & $7 \mathrm{kDa}$ & $\begin{array}{l}10 \% \text { IgE binding } \\
\text { frequency }\end{array}$ & Blomia tropicalis & Unknown \\
\hline 20. & Der p 20 & Arginine kinase & $20 \mathrm{kDa}$ & - & Dermatophagoides pteronyssinus & Unknown \\
\hline 21. & Blo t 21 & Lipid-binding & - & - & Dermatophagoides pteronyssinus & - Mostly unknown \\
\hline & Der p 21 & protein & & & & $-\mathrm{T}_{\mathrm{H}^{2}}$ cells polarization \\
\hline 22. & Der f 22 & $\begin{array}{l}\text { Lipid-binding } \\
\text { protein }\end{array}$ & - & - & Dermatophagoides farinae & Unknown \\
\hline 23. & Der p 23 & $\begin{array}{l}\text { Chitin-binding } \\
\text { protein }\end{array}$ & $14 \mathrm{kDa}$ & - & Dermatophagoides pteronyssinus & Unknown \\
\hline 24. & Der f 24 & Troponin C & $18 \mathrm{kDa}$ & - & Dermatophagoides farinae & Unknown \\
\hline 25 . & - & $\alpha$-tubulin & $51 \mathrm{kDa}$ & - & $\begin{array}{l}\text { Lepidoglyphus destructor } \\
\text { Tyrophagus putrescentiae }\end{array}$ & Unknown \\
\hline 26. & - & $\begin{array}{l}\text { Heat shock } \\
\text { protein } 70\end{array}$ & $70 \mathrm{kDa}$ & - & $\begin{array}{l}\text { Blomia tropicalis } \\
\text { Dermatophagoides farinae }\end{array}$ & Unknown \\
\hline
\end{tabular}

*Allergens nomenclature is registered with International Union of Immunological Societies (www.allergen.org)

Typical symptoms due to HDM allergy include coughing, sneezing, nasal or oral itchiness, shortness of breath, allergic conjunctivitis, rhinorrhea and lethargy. HDM mediated asthma may result in tightness or discomfort in chest, wheezing and dyspnea (Huss et al. 2001; Bourdin et al. 2009; Shafique et al. 2018). Cross reactivity due to $\mathrm{HDM}$ allergen sensitivity may also result in development of allergic sensitization to mollusks and shellfish.

\section{Prevention and Management}

Prevention is the most effective intervention against HDM allergy. Household bedding, mattresses, pillow etc. may be encased in plastic to prevent penetration. Infested items, heavy fabric drapes and carpeting should either be removed, periodically replaced or washed weekly in hot

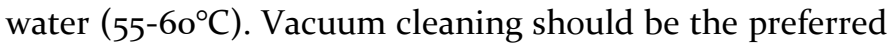
method of cleaning over dry dusting. 


\section{Non-Biting Flies}

Flies are a common environmental occurrence. They are not only responsible for communicating parasites and infectious diseases as vectors for various viral, bacterial, protozoan, and fungal pathogens (Khamesipour et al. 2018) but are also implicated in aeroallergen induced allergy (Sgambato et al. 1987). Urticaria, rhinitis, erythema, conjunctivitis and respiratory difficulties have been associated with exposure to flies and their maggots (Kino et al. 1987; Martinez et al. 1997). Occupational allergy due to flies is affected by several factors, such as availability of shelter, water and nutritional sources (Tee et al. 1985; Kraut et al. 1994). Some common biting and non-biting flies implicated in allergic reactions are shown in Figure 6.

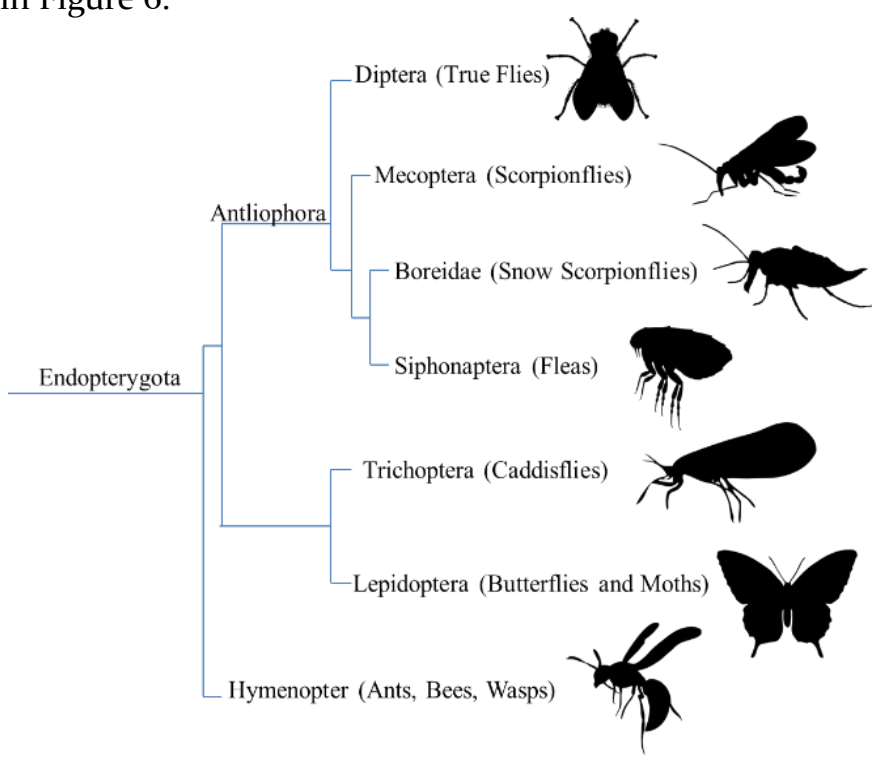

Fig. 6: Cladogram of biting and non-biting flies.

\section{Common Housefly (Musca domestica)}

Houseflies belong to the order Diptera, and are known as true flies. Although the common housefly (Musca domestica) is recognized as a cause of nasal allergy for many years (Jamieson 1938; Tee et al. 1985), relatively fewer incidences are reported as case studies. Housefly emanated particles (wings and body sheddings, follicles, excreta) and body secretions (saliva) are potent IgEmediated aeroallergens responsible for asthma exacerbations, especially in children (Lierl et al. 1994). Previous studies have confirmed high-affinity IgE cross reactions between the sera of sensitized individuals against protein molecules from housefly extracts (Baldo and Panzani 1988; Martinez et al. 1997). Occupational allergy to houseflies has been reported in infested barn workers (Wahl and Fraedrich 1997), farmers (Focke et al. 2003) and pharmaceutical industry workers engaged in fly breeding (Tee et al. 1985; Tas et al. 2007).

\section{Bluebottle Fly (Calliphora vomitoria)}

The bluebottle fly (Calliphora vomitoria) is twice the size of a common housefly (Whitworth 2006). It is named so because of characteristic black and bright metallic blue abdominal markings. Wings of this fly are transparent, body and legs are covered with dark hair-like bristles, while antennae are short and club-shaped (Chinery and Legrand 2012). Calliphora maggots are used in live bait fishing. Bluebottle fly allergy is mostly reported by fishing bait breeders (Pazzaglia et al. 2003), occupational and recreational fishermen (Félix-Toledo et al. 2005). Symptoms typically appear within an hour of exposure, resulting in itchiness of the hands which extends to face and neck, accompanied by urticaria and rhinoconjunctivitis. Respiratory difficulties, such as congestion in chest and wheeze, appear after 6-8 hours and progressively worsen with time (Stockley et al. 1982; Siracusa et al. 2003). IgEimmunoblotting has revealed protein bands of 14, 28, 40, 46, 73 and kDa weights (Tideman and Elberink 2009; Porcel Carreño et al. 2013). Calliphora allergy prevalence has not been extensively investigated.

\section{Caddis Fly (Rhyacophilidae Stephens)}

Rhyacophilidae are free and parasitic insects. Adult flies appear like moths, since they are closely related to the Lepidoptera. They have bristly and hairy membranous wings. Larvae use silk to encase themselves as pupae (Wiggins 2004; Ali et al. 2020). Investigation of caddis fly extracts has revealed a spectrum of allergenically active low molecular weight proteins (Shulman et al. 1962; Rapp et al. 1962). Post exposure symptoms include epiphora, rhinorrhea, cough, wheeze, and shortness of breath. Incidences of hypersensitivity increase during summer season when new flies are hatched. Power plant managing workforce has been extensively studied in relation to occupational allergy to caddis flies. Caddis flies are attracted to station lights, water, nutritional sources and shelter due to human inhabitation. Adult caddisflies are attracted to both UV and visible spectrums (Kimura and Kuranishi 2020). These flies are sucked into and pulverised by the power turbines and dispersed as aeroallergens (Kraut et al. 1994; Miedinger et al. 2010; McNulty and Divekar 2017). A recent study has reported that professional cleaning workers exhibit airway inflammation and hypersensativity to caddis fly allergens (Lima et al. 2017). Skin prick tests (SPTs) invoked 6o\% positive results against laboratory prepared caddis fly antigen (LCFA) collected from power plant sites and 39\% positive results from commercial caddis fly antigen (CCFA) (Kraut et al. 1994).

\section{Roaches}

Cockroaches are primitive but common Neopteran insects, having global distribution. Cockroaches don't have any specialized adaptations, apart from chewing mouthparts called mandibles, allowing them to feed on a great variety of nutritional sources alongside human foods such as starches (paper, leather, glue), fiber (clothing), organic debris (shedding, hair follicles, skin flakes) and other dead insects (Bell 1982). Of the total 4,6oo cockroach species described so far, only 50 are considered pestilence 
Table 6: Cockroach allergens and their biological roles (IUIS Allergen Nomenclature)

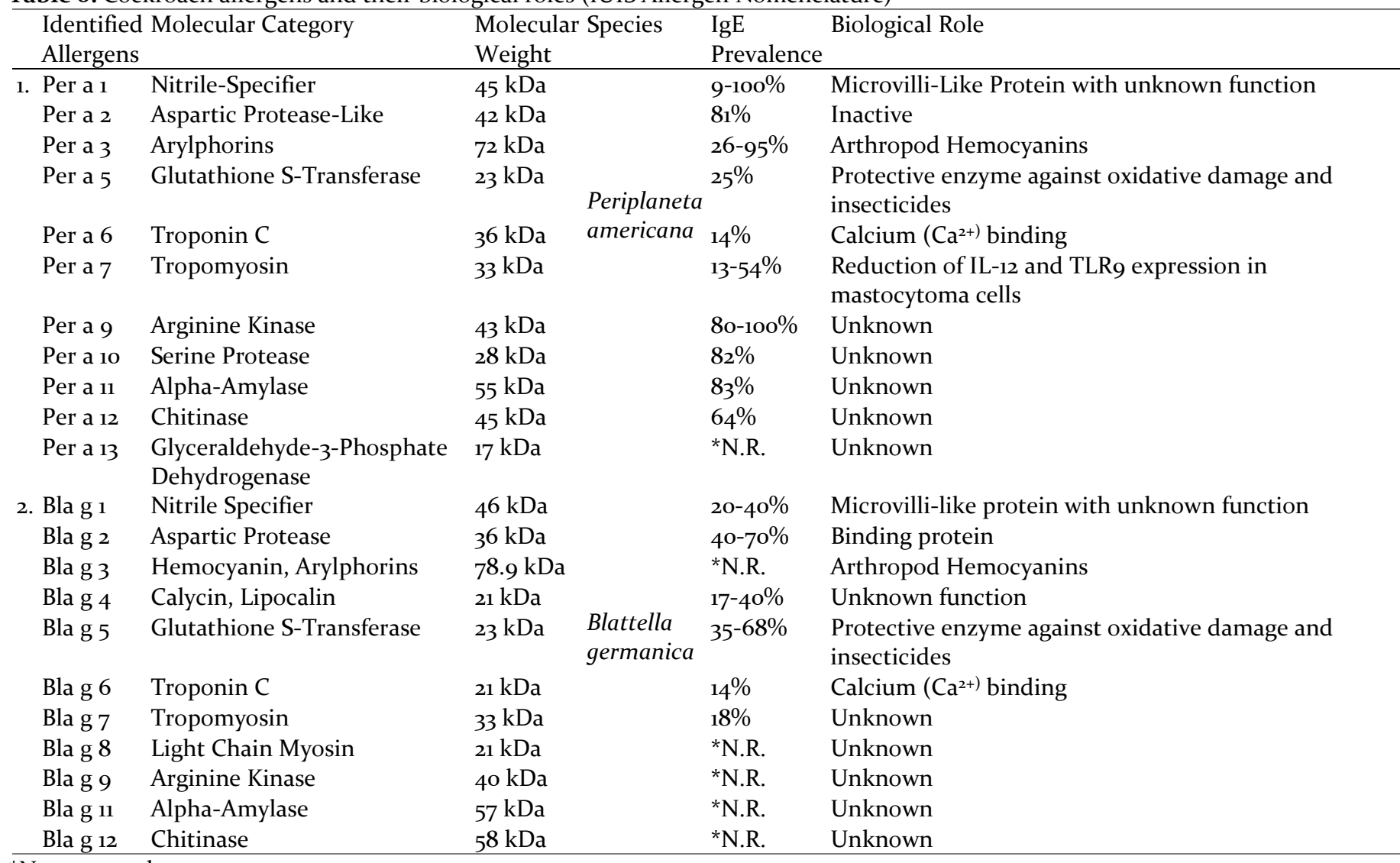

${ }^{*}$ Not reported.

associated with human dwellings (Roth and Willis 1952; Cornwell 1968). Five of the most frequently occurring cockroach pests are the American cockroach (Periplaneta americana), German cockroach (Blattella germanica), Asian cockroach (Blattella asahinai), Oriental cockroach (Blatta orientalis) and Turkestan cockroach (Blatta lateralis) (Helm et al. 1990; Kang et al. 1996; Memona et al. 2017). Cockroaches are not only vectors of infectious diseases and parasites (Koehler et al. 1990), but allergens derived from cockroach secretions, saliva, excreta, exoskeletons, egg casings and dead bodies are source of powerful aeroallergens implicated in allergic reactions (Lehrer et al. 1991; Arruda and Chapman 2001). Allergic rhinitis, eczema and asthma are amongst the most prevalent chronic disorders in the world, especially in children. An alarming increase in disease incidence and economic burden has been observed in the past few decades (Beasley et al. 2000; Fineman 2002). Genetic variability of a population is not as rapid as environmental variations, which makes aeroallergens largely responsible for allergic diseases (Sears et al. 1989; Sporik et al. 1990).

Particles bearing cockroach allergens are heavy and settle rapidly, becoming air-borne only when disturbed (de Blay et al. 1997). Various investigative studies have detected clinically significant cockroach allergen concentrations in settled dust in kitchen surfaces, lounges, libraries, gymnasiums, cafeterias, hallways, offices, mattresses and floors (Sarpong et al. 1997). Some closely related cockroach species cause cross reactivity due to their similarities. Per a 1 (Periplaneta americana) and Bla g 1 (Blattella germanica) allergens show cross-reactivity with female Anopheles gambiae mosquitoes, with 30\% homology (Melen et al. 1999). Other proteins from these two species show moderate homology with other allergenic arthropods, including glutathioneS-transferase of dustmites and other insects, and tropomyosins of shellfish and dust mites (Reese et al. 1999). List of 3 most prevalent cockroach species is given in Table 6 .

\section{Prevalence and Epidemiology}

Cockroach allergy has been attributed to both genetic and environmental factors (Sohn and Kim 2012). Socioeconomic factors and population density are also important factors (Alp et al. 2001; Leaderer et al. 2002; Mendy et al. 2020). Earliest clinical investigations have implicated cockroach allergen sensitization in $40 \%$ asthmatics (Bernton and Brown 1964; Kang et al. 1979). A study in Korea found cockroach infestations in $62 \%$ of investigated homes in Seoul. Four species were discovered, Blattella germanica (36.2\%), Periplaneta americana (33.3\%), Periplaneta japonica (1.1\%) and Periplaneta Fulginosa (1.7\%) (Lee 1998). Immunological investigations against cockroach extracts in Korean population have revealed $18.7 \%$ SPT positivity, elevated IgE levels and $37.5 \%$ bronchial constriction (Lee et al. 1993).

Mounting evidence has suggested that cockroach allergen sensitized patients are exposed to cockroach allergens in their own homes (Call et al. 1992; Gelber et al. 1993; Chapman et al. 1996). Cockroach infestations are a major problem in inner city areas and schools, where allergen 
levels are clinically significant (Call et al. 1992; Sarpong et al. 1997; Wang et al. 2009). In United States, 36.8\% children living in inner city areas were allergic to cockroaches (Rosenstreich et al. 1997). Development of wheeze in one year old children in metropolitan Boston was significantly associated with exposure to cockroach allergens during the first 3 months of their life (Gold et al. 1999; Donohue et al. 2008). Although suburban houses have relatively lower allergens, however 30\% suburban and middle-class homes showed detectable levels of cockroach allergens (Gaffin and Phipatanakul 2009). Improved garbage disposal systems and frequent use of pesticides may have contributed to relatively decreased infestation rates (Lee et al. 1993). Cockroach extermination, along with frequent and through cleaning in homes, schools and restaurants, can reduce allergens to clinically insignificant or even undetectable levels (Liccardi et al. 2000; Eggleston and Arruda 2001).

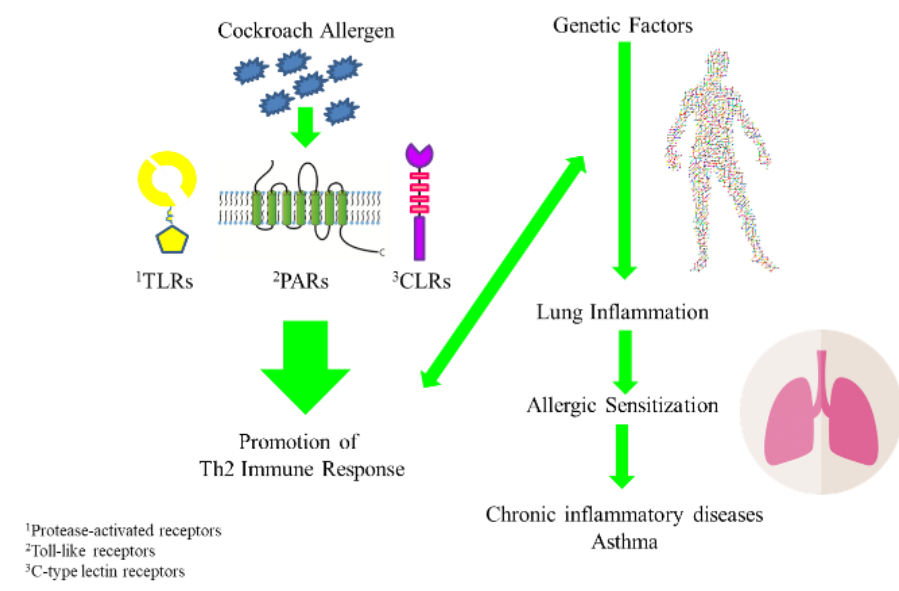

Fig. 7: Mechanism illustrating cockroach allergen-induced allergic sensitization (Gao 2012).

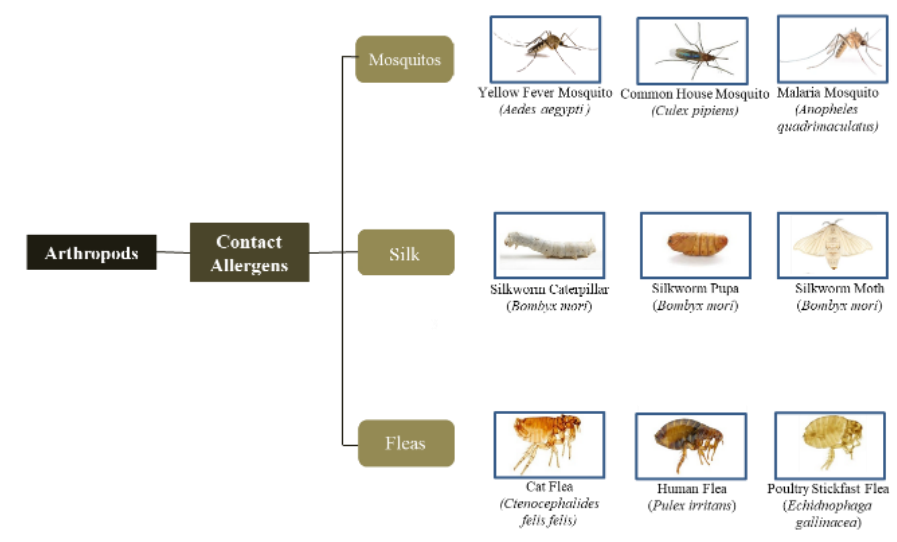

Fig. 8: Common arthropods species implicated in contact allergy.

Cockroach allergy has been reported as one of the most frequent environmental allergens in Pakistan (Abbas et al. 2015). Memona et al. (2017) conducted a collection-based survey and reported that B. germanica had the highest diversity indices and is the most dominant indoor cockroach species in Lahore, Pakistan. Furthermore, a survey-based study carried out in Southern Punjab,
Pakistan revealed that about $80 \%$ people, who participated in the survey, were unaware of diseases transmitted by cockroaches (Naeem et al. 2014). A population-based study in Karachi, Pakistan concluded that out of 27 allergens tested on 88 individuals including children and adults, 33\% exhibited moderate rates of reactivity to cockroach allergens, with $4.5 \%$ showed high reactivity rates (Abbas et al. 2015).

\section{Clinical Manifestations}

Cockroach allergens increase cellular penetration by disturbing the airway epithelial integrity, which not only leads to increased sensitization to cockroach allergen but also activates the innate immunity's cellular components such as dendritic cells, promoting Th2 response ultimately culminating in lung inflammation (Figure 7). Cockroach allergen sensitization is overwhelmingly associated with allergic respiratory distress, as well as development of asthma and asthma-like symptoms. Exposure to higher levels of cockroach allergens has greater asthma related hospitalizations and morbidities in cockroach antigen sensitized patients, especially in children. Studies show that a quarter of asthmatic children are sensitized to cockroach allergens (Rosenstreich et al. 1997; Stelmach et al. 2002.). Cockroach allergens responsible for asthma exacerbations are usually found in detectable levels in the house.

Cockroach allergen is a strong risk factor associated with severity and frequency of childhood allergies and asthma, especially in inner city residents, where higher cockroach infestations are recorded. Rates of emergency room visits, hospitalizations and days of school or work days missed are also higher in inner city residents, mostly due to cockroach allergen induced IgE levels (Gao 2012; Fukutomi and Kawakami 2021). Certain clinical markers, such as wheeze, inflammation and IgE monitoring, are potent indicators of sensitization to cockroach allergen and surrogate measure of the amount of exposure. The probability of cockroach allergen sensitization increases with increased exposure to the allergen. Sanitization often acts as a gateway to development of asthma and inflammatory respiratory diseases.

\section{Prevention and Management}

Exposure to cockroach allergen is of public health concern. Sufficient data suggests its association in the development of chronic respiratory diseases, such as asthma (Bourdin et al. 2009; Wang et al. 2021). Experts recommend eradication of cockroaches to reduce environmental allergens. A combination of pest management through pesticides, traps and general cleanliness, combined with patient and family education, are the effective approaches. Reservoir cleansing may be achieved through cleaning by using vacuum cleaners, washing of carpets, rugs and drapes with hot water and detergents. Professional cleaning and installation of HEPA filters can also reduce cockroach infestations. 
Immunotherapy coupled with preventive measures can result in beneficial treatment for the sensitized patients. Several FDA standardized extracts are commercially available for immunotherapy; however their efficacy, besides in limited clinical trials, is debatable (Portnoy et al. 2013). There is no effective dosage and no standard symptom-based medications have so far been developed. However, placebo studies in India have shown significant clinical improvement after one year of immunotherapy (Srivastava et al. 2011).

\section{Contact Allergens}

Contact mediated irritation or allergic reaction to certain arthropods has been recorded as early as ancient Rome (Burgess 1993). Incidences of silk worm caterpillar allergy have existed as long as sericulture itself. Acute or chronic exposure to larvae, caterpillar or moth hairs cause irritation, usually followed by inflammation. The irritants are characterized either as histamines or soluble proteins which trigger histamine. Direct contact with larvae and caterpillar hair can cause permanent damage, such as when shed hair are blown due to wind and lodged in eyes. Arthropod contact allergens have seasonal density proportional to moth populations.

Occupational allergies associated with arthropods are well documented (Fukutomi and Kawakami 2021). Workers in arthropod breeding facilities, such as in laboratories, fly fishing farms and sericulture industry, routinely report contact allergies. Typical symptoms exhibited are rhiniconjunctival reactions, urticaria and asthma. Clinical symptoms develop rapidly in atopic individuals in comparison to non-atopic individuals. Specific IgE levels correspond to the levels of exposure to allergens. In most cases, patients are unaware of their allergies (Burgess 1993; Naeem et al. 2014).

\section{Mosquitoes}

Dermal inflammatory reactions to mosquito bites are common, especially in tropical and sub-tropical regions. However, anaphylactic reactions to mosquito bites are very rare (Larry 2002). A total of 19 proteins found in mosquito salivary gland extracts induce IgE mediated allergenic responses (Boorman 1987). Mosquito shedding, including wings, hair and feces, may become aerosolized and cause allergic reactions if inhaled. This is especially evident in occupational hazard studies, where workers are exposed to mosquitos such as when rearing mosquitos or when working in rice fields (Fukutomi and Kawakami 2021). Allergic reactions to inhaled mosquito allergens are typical hypersensitivity-I reactions, culminating in sneezing, dizziness, shortness of breath or even in some severe cases anaphylaxis (McCormack et al. 1995).

Positive skin prick tests using Aedes sp., Culex sp. and Anopheles sp. along with elevated specific IgE levels suggest sensitivity to these commonly found mosquito species. Immunotherapy has proved effective, however, it is not widely used and its effectiveness has not yet been clinically determined. Preventive measures include mosquito eradication or use of repellents. Evidence of natural desensitization due to repeated bites has also been recorded (McKiel and West 1961).

\section{Silk Proteins}

Allergic reaction to silkworm caterpillar (Bombyx mori) has been reported and many of its metabolites are now recognized as allergens capable of inducing severe hypersensitivity reactions (Suzuki et al. 1995). A recent study analyzed silkworm feces larva, pupa, moth and silk for potential allergens and identified 45 allergens. Furthermore, homology comparison analysis suggested cross-reactivity with several other arthropod allergens, including Aedes aegypti, Dermatophagoides farinae, Malassezia furfur, Triticum aestivum and Tyrophagus putrescentiae (He et al. 2021). Mounting evidence suggests that components of the silkworms cocoon and even silk pose allergic threat to sanitized populations.

Fleas

Fleas are quite common in occurrence, and infest humans and domestic animals. They are disease vectors and are responsible for transmission of pathogens and allergens (Souza 1997). Flea bites may induce hypersensitivity responses characterized as Flea Allergic Dermatitis (FAD), due to allergens present in the salivary glands (Halliwell 1984; Esch et al. 2001). Adult fleas are permanent ectoparasites. This ensures continued longevity, a constant source of nutrition, reproductive opportunities and large egg production. Common fleas are shown in Figure 8.

\section{REFERENCES}

Aalberse RC, 200o. Structural biology of allergens. Journal of Allergy and Clinical Immunology 106: 228-238.

Abbas $\mathrm{N}$ et al., 2015. Environmental and food allergens reactivity and its association with total IgE, age and gender in Karachi, Pakistan. Journal of Allergy \& Therapy 6: 215; doi: 10.4172/2155-6121.1000215.

Afzaal Z et al., 2016. Stock assessment of blue swimming crab Portunus pelagicus (Linnaeus, 1758) from Pakistani waters (Northern, Arabian Sea). Pakistan Journal of Zoology 48: 1531-1541.

Ali $T$ et al., 2020. Checklist of the caddisfly family Rhyacophilidae (Insecta: Trichoptera) in India. Insecta Mundi 0809: 1-17.

Alp $\mathrm{H}$ et al., 20o1. Cockroach allergy appears early in life in inner-city children with recurrent wheezing. Annals of Allergy, Asthma and Immunology 86: 51-54.

Arlian LG, 2002. Arthropod allergens and human health. Annual Review of Entomology 47: 395-433.

Arlian LG et al., 1992. Prevalence of dust mites in the homes of people with asthma living in eight different geographic areas of the United States. Journal of Allergy and Clinical Immunology 90: 292-300.

Arruda LK and Chapman MD, 2001. The role of cockroach allergens in asthma. Current Opinion in Pulmonary Medicine 7: 14-19. 
Baldo BA and Panzani RC, 1988. Detection of IgE antibodies to a wide range of insect species in subjects with suspected inhalant allergies to insects. International Archives of Allergy and Immunology 85: 278-287.

Beasley R et al., 20oo. Prevalence and etiology of asthma. Journal of Allergy and Clinical Immunology 105: S466$\mathrm{S}_{472 .}$

Bell WD, 1982. The American cockroach. Springer Science and Business Media.

Bernton $\mathrm{H}$ and Brown $\mathrm{H}$, 1964. Insect allergy preliminary studies of the cockroach. Journal of Allergy and Clinical Immunology 35: 506-513.

Bonlokke JH et al., 2012. Snow crab allergy and asthma among Greenlandic workers-a pilot study. International Journal of Circumpolar Health 76: 1.

Boorman J, 1987. Induction of salivation in biting midges and mosquitoes, and demonstration of virus in the saliva of infected insects. Medical and Veterinary Entomology 1: 211-214.

Bourdin A et al., 2009. Upper airway: Allergic rhinitis and asthma: United disease through epithelial cells. Thorax 64: 999-1004.

Burgess I, 1993. Allergic reactions to arthropods. Indoor Environment 2: 64-70.

Calderón MA et al., 2015. Respiratory allergy caused by house dust mites: what do we really know?. Journal of Allergy and Clinical Immunology 136: 38-48.

Call RS et al., 1992. Risk factors for asthma in inner city children. Journal of Pediatrics 121: 862-866.

Casset A et al., 2006. Inhaled formaldehyde exposure: Effect on bronchial response to mite allergen in sensitized asthma patients. Allergy 61: 1344-1350.

Chan TY, 1998. Shrimps and prawns. FAO species identification guide for fishery purposes. The Living Marine Resources of the Western Central Pacific 2: 851-966.

Chapman MD et al., 1996. Cockroach allergens and their role in asthma. In: Kay $\mathrm{AB}$ (editor). Allergy and Allergic Diseases. Oxford, UK: Blackwell Science Ltd; pp: 942-951.

Chapman MD et al., 2007. Proteases as Th2 adjuvants. Current Allergy Asthma Reports 7: 363-367.

Chinery M and Legrand J, 2012. Association des amis du Laboratoire d'entomologie du Muséum (France). Insectes de France et d'Europe occidentale Flammarion 2012: 214-215.

Christensen LH et al., 2008. Several distinct properties of the IgE repertoire determine effector cell degranulation in response to allergen challenge. Journal of Allergy and Clinical Immunology 122: 298304.

Colloff MJ, 1998. Taxonomy and identification of dust mites. Allergy 53: 7-12.

Constant SL and Bottomly K, 1997. Induction of Th1 and Th2 $\mathrm{CD}_{4+} \mathrm{T}$ cell responses: The alternative approaches. Annual Review of Immunology 15: 297322.

Cookson W, 1999. The alliance of genes and environment in asthma and allergy. Nature 402: B5-B11.
Cornwell PB, 1968. The Cockroach. Volume 1. Hutchinson, London, UK.

Custovic A et al., 1999. Dust mite allergens are carried on not only large particles. Pediatric Allergy and Immunology 10: 258-26o.

de Blay F et al., 1997. Dust and airborne exposure to allergens derived from cockroach (Blattella germanica) in low-cost public housing in Strasbourg (France). Journal of Allergy and Clinical Immunology 99(1): 107-112.

Devereux G and Seaton A, 2005. Diet as a risk factor for atopy and asthma. Journal of Allergy and Clinical Immunology 115: 1109-1117.

Dhaliwal AK et al., 2021. Sensitivity in allergic asthmatic subjects towards house dust mite allergens. Systematic and Applied Acarology 26: 75-84.

Dohi $\mathrm{M}$ et al., 1991. Food-dependent, exercise induced anaphylaxis: A study on 11 Japanese cases. Journal of Allergy and Clinical Immunology 87: 34-40.

Donohue KM et al., 2008. Anti-cockroach and anti-mouse IgE are associated with early wheeze and atopy in an inner-city birth cohort. Journal of Allergy and Clinical Immunology 122: 914-920.

Eggleston PA and Arruda LK, 2001. Ecology and elimination of cockroaches and allergens in the home. Journal of Allergy and Clinical Immunology 107: S422$\mathrm{S}_{429}$.

Esch RE et al., 2001. Common allergenic pollens, fungi, animals, and arthropods. Clinical Reviews in Allergy and Immunology 21: 261-292.

FAO-FBS, 2015 online resource. Food and Agriculture Organization of the United Nations. http://www.fao.org/faostat/en/.

Félix-Toledo $\mathrm{R}$ et al., 2005. Allergy to sea fishing baits. Journal of Investigational Allergology and Clinical Immunology 15: 216.

Fineman SM, 2002. The burden of allergic rhinitis: Beyond dollars and cents. Annals of Allergy, Asthma and Immunology 88: 2-7.

Focke M et al., 2003. Specific sensitization to the common housefly (Musca domestica) not related to insect panallergy. Allergy 58: 448-451.

Fukutomi Y and Kawakami Y, 2021. Respiratory sensitization to insect allergens: Species, components and clinical symptoms. Allergology International 70(3): 303-312.

Gaffin JM and Phipatanakul W, 20o9. The role of indoor allergens in the development of asthma. Current Opinion in Allergy and Clinical Immunology 9: 128135 .

Gao P, 2012. Sensitization to cockroach allergen: Immune regulation and genetic determinants. Clinical and Developmental Immunology 2012: 563760.

Gautrin D et al., 2010. Occupational asthma and allergy in snow crab processing in Newfoundland and Labrador. Occupational and Environmental Medicine 67: 17-23.

Gelber LE et al., 1993. Sensitization and exposure to indoor allergens as risk factors for asthma among patients presenting to hospital. The American Review of Respiratory Disease 147: 573-578. 
Gold DR et al., 1999. Predictors of repeated wheeze in first year of life. American Journal of Respiratory and Critical Care Medicine 160: 227-236.

Goldsby RA et al., 2003. Immunology. 5th Edition, WH Freeman. New York, USA.

Greiner AN et al., 2011. Allergic rhinitis. The Lancet 378: 2112-2122.

Guerrant RL et al., 2006. Tropical Infectious Diseases: Principles, pathogenesis and practice. $2^{\text {nd }}$ Edition, Elsevier Churchill Livingston, Philadelphia, USA; pp: 77-81.

Halliwell $\mathrm{R}$ and the International Task Force on Atopic Dermatitis. 2006. Revised nomenclature for veterinary allergy. Veterinary Immunology and Immunopathology 114: 207-208.

Halliwell REW, 1984. Managing flea-allergy dermatitis -3 . Factors in the development of flea-bite allergy. Veterinary Medicine and Small Animal Clinician 79: 1273-1278.

He W et al., 2021. Identification of potential allergens in larva, pupa, moth, silk, slough and feces of domestic silkworm (Bombyx mori). Food Chemistry 28: 130231.

Helm RM et al., 1990. Shared allergenic activity in Asian (Blattella asahinai), German (Blattella germanica), American (Periplaneta americana), and Oriental (Blatta orientalis) cockroach species. International Archives of Allergy and Immunology 92: 154-161.

Huss $\mathrm{K}$ et al., 2001. House dust mite and cockroach exposure are strong risk factors for positive allergy skin test responses in the childhood asthma management program. Journal of Allergy and Clinical Immunology 107: 48-54.

Hussain A et al., 2019. Aero and food allergens sensitization patterns in a clinic-based sample in Pakistan: A one year retrospective study. Pakistan Journal of Zoology 51(4): 1429-1437.

Hussain $\mathrm{M}$ et al., 2020. Frequency of common food allergens among patients referred to a tertiary care center. Pakistan Armed Forces Medical Journal 70: 201-204.

Ibarrola I et al., 2008. Expression of a recombinant protein immunochemically equivalent to the major Anisakis simplex allergen Ani $\mathrm{s}$ 1. Journal of Investigational Allergology and Clinical Immunology 18: 78-83.

IUIS Allergen Nomenclature, 1984. WHO/IUIS Allergen Nomenclature Sub-Committee. www.allergen.org.

Jabbar-Lopez ZK et al., 2020. Longitudinal analysis of the effect of water hardness on atopic eczema: Evidence for gene-environment interaction. British Journal of Dermatology 183(2): 285-293.

Jacquet A, 2013. Innate immune responses in house dust mite allergy. ISRN Allergy, 2013: 735031.

Jamieson HC, 1938. The housefly as a cause of nasal allergy. Journal of Allergy 9: 273-274.

Janeway $C$ et al., 2001. Immunobiology: Fifth Edition. Garland Science, New York and London.

Jeong KY et al., 2010. Enzymatic activities of allergen extracts from three species of dust mites and cockroaches commonly found in Korean homes. The
Korean Iournal of Parasitology 48: 151-155.

Jeong KY et al., 2006. Recombinant allergens for diagnosis and immunotherapy of allergic disorders, with emphasis on cockroach allergy. Current Protein and Peptide Science 7: 57-71.

Jeong SK et al., 2008. Mite and cockroach allergens activate protease-activated receptor 2 and delay epidermal permeability barrier recovery. Journal of Investigative Dermatology 128: 1930-1939.

Johansson SG et al., 200o. Prevention of allergy and asthma interim report-based on the WHO/IAACI Meeting on the Primary Prevention of Allergy and Asthma-5-6 December 1999-Geneva. Switzerland Allergy 55: 1069-1085.

Kagen SL, 1990. Inhalant allergy to arthropods. Clinical Reviews in Allergy 8: 99-125.

Kamath SD et al., 2014. Molecular and immunological approaches in quantifying the air-borne food allergen tropomyosin in crab processing facilities. International Journal of Hygiene and Environmental Health 217: 740-750.

Kanchan $\mathrm{K}$ et al, 2021. Current insights into the genetics of food allergy. Journal of Allergy and Clinical Immunology 147: 15-28.

Kang B and Chang JL, 1985. Allergenic impact of inhaled arthropod material. Clinical Reviews in Allergy 3: 363375 .

Kang B et al., 1979. Cockroach cause of allergic asthma. Its specificity and immunologic profile. Journal of Allergy and Clinical Immunology 63: 8o-86.

Kang BC et al., 1996. Experimental asthma developed by room air contamination with cockroach allergen. International Archives of Allergy and Immunology 111: 299-306.

Kay AB, 2001. Allergy and allergic diseases. New England Journal of Medicine 344: 30-37.

Khamesipour F et al., 2018. A systematic review of human pathogens carried by the housefly (Musca domestica L.). BMC Public Health 18: 1-5.

Kim CW and Hong CS, 2007. Allergy to miscellaneous household arthropods. Protein and Peptide Letters 14: 982-991.

Kimura G and Kuranishi RB, 2020. Effect of visible light sticks for collecting of adult caddisflies (Trichoptera): A preliminary field study. Zoosymposia 18: 153-159.

Kinet JP, 1990. The high-affinity receptor for IgE. Current Opinion in Immunology 2: 499-505.

Kino $\mathrm{T}$ et al., 1987. Allergy to insects in Japan: III. High frequency of IgE antibody responses to insects (moth, butterfly, caddis fly, and chironomid) in patients with bronchial asthma and immunochemical quantitation of the insect-related airborne particles smaller than 10 $\mu \mathrm{m}$ in diameter. Journal of Allergy and Clinical Immunology 79: 857-866.

Koehler PG et al., 1990. Cockroaches. In: Mallis A (editor). Handbook of Pest Control: The behavior, life history and control of household pests. 7th Edition. Franzak and Foster, Cleveland, pp: 101-174.

Kraut A et al., 1994. Occupational allergy after exposure to caddis flies at a hydroelectric power plant. 
Occupational and Environmental Medicine 51: 408413.

Larry GA, 2002. Arthropod allergens and human health. Annual Review of Entomology 47: 395-433.

Lauzon-Joset JF et al., 2020. Oestrogen amplifies preexisting atopy-associated Th2 bias in an experimental asthma model. Clinical and Experimental Allergy 50: 391-400.

Leaderer BP et al., 2002. Dust mite, cockroach, cat, and dog allergen concentrations in homes of asthmatic children in the northeastern United States: Impact of socioeconomic factors and population density. Environmental Health Perspectives 110: 419-425.

Lee AJ et al., 2012. Shellfish allergy, an Asia-Pacific perspective. Asian Pacific Journal of Allergy and Immunology 30: 3 .

Lee KY, 1998. Allergens detected by allergy skin test in children with atopic diseases. Pediatric Allergy and Respiratory Disease Suppl: S43-48.

Lee SW et al., 2021. Ubiquitous overexpression of chromatin remodeling factor $\mathrm{SRG}_{3}$ exacerbates atopic dermatitis in NC/Nga mice by enhancing Th2 immune responses. International Journal of Molecular Sciences 22: 1553.

Lee SY et al., 1993. Cockroach hypersensitivity in Korean atopic asthmatic children. Pediatr Allergy, Asthma and Respiratory Disease 3: 89-97.

Lehrer S et al., 1991. Comparison of cockroach allergenic activity in whole body and fecal extracts. Journal of Allergy and Clinical Immunology 87: 574-580.

Li J et al., 2013. House dust mite sensitization is the main risk factor for the increase in prevalence of wheeze in 13-to 14-year-old schoolchildren in Guangzhou city, China. Clinical and Experimental Allergy 43: 1171-1179.

Liccardi G et al., 200o. Pets and cockroaches: Two increasing causes of respiratory allergy in indoor environments. Characteristics of airways sensitization and prevention strategies. Respiratory Medicine 94: 1109-1118.

Lierl MB et al., 1994. Prevalence of insect allergen specific IgE in allergic asthmatic children in Cincinnati, Ohio. Annals of Allergy, Asthma and Immunology 72: 45-50.

Lima CF et al., 2017. Inflammatory cell response, functional and biochemical features of the airways of professional cleaning workers upon exposure in the workplace. Journal of Allergy and Clinical Immunology 139: AB24.

Lintner TJ and Brame KA, 1993. The effects of season, climate, and air-conditioning on the prevalence of dermatophagoides mite allergens in household dust. Journal of Allergy and Clinical Immunology 91: 862867.

Lopata AL et al., 2016. Allergens and molecular diagnostics of shellfish allergy: Part 22 of the series molecular allergology. Allergo Journal International 25(7): 210-218.

Lopata AL et al., 2010. Shellfish allergy. Clinical and Experimental Allergy 40: 850-858.

Mantyjarvi $\mathrm{R}$ et al., 200o. Lipocalins as allergens. Biochimica et Biophysica Acta (BBA)- Protein
Structure and Molecular Enzymology 1482: 308-317.

Marshall NA et al., 1986. Species-specific allergens from the salivary glands of Triatominae (Heteroptera: Reduviidae). Journal of Allergy and Clinical Immunology 78: 430-435.

Martinez A et al., 1997. Importance of tropomyosin in the allergy to household arthropods. Cross-reactivity with other invertebrate extracts. Allergologia et Immunopathologia 25: 118-126.

McCormack DR et al., 1995. Mosquito bite anaphylaxis: Immunotherapy with whole body extracts. Annals of Allergy, Asthma and Immunology 74: 39-44.

McKiel JA and West AS, 1961. Effects of repeated exposures of hypersensitive humans and laboratory rabbits to mosquito antigens. Canadian Journal of Zoology 39: 597-603.

McNulty CM and Divekar R, 2017. Caddis fly allergy in a hydroelectric plant worker, a classic association. Journal of Allergy and Clinical Immunology 139: AB24.

Melen E et al., 1999. Molecular cloning of Per a 1 and definition of the cross reactive Group 1 cockroach allergens. Journal of Allergy and Clinical Immunology 103: 859-864.

Memona $\mathrm{H}$ et al., 2017. Species diversity and distributional pattern of cockroaches in Lahore, Pakistan. Journal of Arthropod-Borne Diseases 11: 249.

Mendy A et al., 2020. Endotoxin clustering with allergens in house dust and asthma outcomes in a US national study. Environmental Health 19: 1-o.

Miedinger D et al., 2010. Occupational asthma to Caddis flies (Phryganeiae). Occupational and environmental medicine 67: 503.

Morgan MS and Arlian LG, 2006. Enzymatic activity in extracts of allergy-causing astigmatid mites. Journal of Medical Entomology 43: 1200-1207.

Naeem A et al., 2014. Life style of people and surveillance of management related to cockroaches in Southern Punjab, Pakistan. Türk Tarım ve Doğa Bilimleri Dergisi 1: 227-233.

Noli C et al., 2013. Veterinary Allergy. John Wiley \& Sons.

O'Neil SE et al., 2006. The chitinase allergens Der p 15 and Der p 18 from Dermatophagoides pteronyssinus. Clinical and Experimental Allergy 36: 831-839.

Pazzaglia $\mathrm{M}$ et al., 2003. Occupational protein contact dermatitis due to Calliphora vomitoria larvae (maggots) bred as fishing bait. Contact Dermatitis 48: 176.

Pomes A et al., 2007. Cockroach allergens: Function, structure and allergenicity. Protein and Peptide Letters 14: 960-969.

Porcel Carreño SL et al., 2013. Allergen profile of Protophormia terraenovae, other species of Calliphoridae, and Lumbricus terrestris in anglers allergic to maggots in caceres, Spain. Journal of Investigational Allergology and Clinical Immunology 2013: 176-182.

Portnoy J et al., 2013. Joint Task Force on Practice Parameters. Environmental assessment and exposure reduction of cockroaches: A practice parameter. Journal of Allergy and Clinical Immunology 132: 802-8o8. 
Radauer $\mathrm{C}$ et al., 2008. Allergens are distributed into few protein families and possess a restricted number of biochemical functions. Journal of Allergy and Clinical Immunology 121: 847-852.

Rapp D et al., 1962. Immunologic studies of the Caddis fly: I. Preparation and characterization of extracts. Journal of Allergy 33: 97-111.

Reese G et al., 1999. Tropomyosin: An invertebrate panallergen. International Archives of Allergy and Immunology 119: 247-258.

Rogers PR and Croft M, 1999. Peptide dose, affinity, and time of differentiation can contribute to the Th1/Th2 cytokine balance. The Journal of Immunology 163: 1205-1213.

Romagnani S, 200o. T-cell subsets (Th1 versus Th2). Annals of Allergy and Asthma Immunology 85: 9-12.

Rona RJ et al., 2007. The prevalence of food allergy: A meta-analysis. Journal of Allergy and Clinical Immunology 120: 638-646.

Rosenstreich DL et al., 1997. The role of cockroach allergy and exposure to cockroach allergen in causing morbidity among inner-city children with asthma. The New England Journal of Medicine: Research and Review 336: 1356-1363.

Roth LM and Willis ER, 1952. The medical and veterinary importance of cockroaches. Miscellaneous Smithsonian Collections 134: 28.

Sarpong SB et al., 1997. Cockroach allergen (Bla g 1) in school dust. Journal of Allergy and Clinical Immunology 99: 486-492.

Sears MR et al., 1989. The relative risks of sensitivity to grass pollen, house dust mite and cat dander in the development of childhood asthma. Clinical and Experimental Allergy 19: 419-424.

Sgambato $\mathrm{F}$ et al., 1987. Inhalation allergy to fly larva. A clinical case. Bollettino Dell'Istituto Sieroterapico Milanese 66: 411-415.

Shafique RH et al., 2018. Sensitivity to house dust mite allergens and prevalence of allergy-causing house dust mite species in Pothwar, Pakistan. Experimental and Applied Acarology 74: 415-426.

Shah SB et al., 2019. Current status of shrimp fishery in Pakistan: Economic role, challenges, opportunities and strategies for aquaculture development. Indian Journal of Geo Marine Sciences 48: 1743-1754.

Shulman S et al., 1962. Immunologic studies of Caddis fly: II. Isolation of the allergenic fractions of Caddis fly extract. Journal of Allergy 33: 438-447.

Shulman S et al., 1963. Immunologic studies of Caddis fly: III. Physical and chemical characterization of the major antigen. Journal of Allergy and Clinical Immunology 34: 1-7.

Sicherer SH and Sampson HA, 2010. Food allergy. Journal of Allergy and Clinical Immunology 125: S116-S125.

Sicherer SH et al., 2004. Prevalence of seafood allergy in the United States determined by a random telephone survey. Journal of Allergy and Clinical Immunology 114: 159-165.

Simpson A et al., 2002. Household characteristics and mite allergen levels in Manchester, UK. Clinical \& Experimental Allergy 32: 1413-1419.
Siracusa A et al., 2003. Prevalence of occupational allergy due to live fish bait. Clinical \& Experimental Allergy 33: 507-510.

Sohn MH and Kim KE, 2012. The cockroach and allergic diseases. Allergy, Asthma and Immunology Research 4: 264 .

Souza CA, 1997. Fleas, flea allergy, and flea control: A review. Dermatology Online Journal 3(2): 7.

Sporik R et al., 199o. Exposure to house-dust mite allergen (Der p I) and the development of asthma in childhood. A prospective study. The New England Journal of Medicine 323: 502-507.

Srivastava D et al., 2011. Clinico-immunological changes post-immunotherapy with Periplaneta americana. European Journal of Clinical Investigation 41: 879-888.

Stelmach I et al., 2002. Cockroach allergy and exposure to cockroach allergen in Polish children with asthma. Allergy 57: 701-705.

Stockley RA et al., 1982. Asthma associated with a circulating IgG antibody to Calliphora maggots. Clinical and Experimental Allergy 12: 151-155.

Sultan F and Khan A, 2013. Infectious diseases in Pakistan: A clear and present danger. The Lancet 381: 2138-2140.

Sultana R et al., 2009. Lobsters from Northern Arabian Sea (Pakistan coast). Pakistan Journal of Scientific and Industrial Research 52: 107-116.

Sun S and Lopata A, 2010. The role of shell fish proteases in allergic diseases and inflammation. Current Allergy and Clinical Immunology 23: 174-179.

Suzuki M et al., 1995. Causative allergens of allergic rhinitis in Japan with special reference to silkworm moth allergen. Allergy 50(1): 23-27.

Takai $\mathrm{T}$ and Ikeda S, 2011. Barrier dysfunction caused by environmental proteases in the pathogenesis of allergic diseases. Allergology International 6o: 25-35.

Tan TT et al., 2012. The role of genetics and environment in the rise of childhood food allergy. Clinical and Experimental Allergy 42: 20-29.

Tas E et al., 2007. Occupational inhalant allergy to the common housefly (Musca domestica). Der Hautarzt; Zeitschrift fur Dermatologie, Venerologie, und Verwandte Gebiete 58(2): 156-16o.

Taylor SL and Lehrer SB, 1996. Principles and characteristics of food allergens. Critical Reviews in Food Science and Nutrition 36: S91-S118.

Tee RD et al., 1985. Occupational allergy to the common house fly (Musca domestica): Use of immunologic response to identify atmospheric allergen. Journal of Allergy and Clinical Immunology 76: 826-831.

Terreehorst I et al., 2002. Prevalence and severity of allergic rhinitis in house dust mite-allergic patients with bronchial asthma or atopic dermatitis. Clinical and Experimental Allergy 32: 1160-1165.

Thomas WR, 2010. Geography of house dust mite allergens. Asian Pacific Journal of Allergy and Immunology 28: 211-224.

Tideman SW and Elberink JH, 20o9. Allergy while fishing. Nederlands Tijdschrift voor Geneeskunde 153: A692. 
Trompette A et al., 2009. Allergenicity resulting from functional mimicry of a Toll-like receptor complex protein. Nature 457: 585-588.

Vaillant AA et al., 2020. Atopy. StatPearls Publishing.

Vercelli D, 2008. Discovering susceptibility genes for asthma and allergy. Nature Reviews in Immunology 8: 169-182.

Villacis $\mathrm{J}$ et al., 2006. Do shrimp-allergic individuals tolerate shrimp-derived glucosamine? Clinical and Experimental Allergy 36: 1457-1461.

Von Pirquet C, 1906. Allergie. Munchener Medizinische Wochenschrift 53: 1457-1458.

Wahl R and Fraedrich J, 1997. Occupational allergy to the housefly (Musca domestica). Allergy 52: 236-238.

Wang $J$ et al., 2009. Effect of environmental allergen sensitization on asthma morbidity in inner-city asthmatic children. Clinical and Experimental Allergy 39: 1381-1389.
Wang $J$ et al., 2021. Asthma and allergic rhinitis among young parents in China in relation to outdoor air pollution, climate and home environment. Science of the Total Environment 751: 141734.

Wang JY, 2013. The innate immune response in house dust mite-induced allergic inflammation. Allergy Asthma Immunologic Research 5: 68-74.

Whitworth T, 2006. Keys to genera and species of blow flies (Diptera: Calliphoridae) of America north of Mexico. Proceedings of the Entomological Society of Washington 108: 689-725.

Wiggins GB, 2004. Caddisflies: The underwater architects. University of Toronto Press, Toronto, Canada.

Yong TS and Jeong KY, 2009. Household arthropod allergens in Korea. The Korean Iournal of Parasitology 47: S143. 